Available online at www.easdprocedia.org

EASD Procedia EURODYN (2020) 4272-4281

EASD

Procedia
EURODYN 2020

XI International Conference on Structural Dynamics M. Papadrakakis, M. Fragiadakis, C. Papadimitriou (eds.) Athens, Greece, 23-26 November 2020

\title{
DAMAGE ASSESSMENT OF CHURCHES IN THE CITY OF CAMERINO AFTER THE 2016 CENTRAL ITALY SEISMIC SEQUENCE
}

\author{
E. Giordano ${ }^{1}$, A. Ferrante ${ }^{1}$, F. Clementi ${ }^{1}$ and S. Lenci ${ }^{1}$ \\ ${ }^{1}$ Dept. of Civil and Building Engineering, and Architecture, Polytechnic University of Marche, Anco- \\ na, Italy \\ e-mail: \{e.giordano,a.ferrante\}@pm.univpm.it, \{francesco.clementi,lenci\}@univpm.it
}

Keywords: Central Italy Earthquakes, Masonry churches, Finite Element Model, Linear Dynamic Analysis, Total Strain Crack Model, Non-Linear Static Analysis

\begin{abstract}
In the present work, the importance of considering the exact nonlinear and threedimensional behavior of masonry structures is shown, in order to highlight all the structural deficiencies of different churches damaged by the last Centre Italy earthquake in the city of Camerino. For this purpose, the exact geometries of the structures are reconstructed, while information regarding the mechanical properties of masonry material are derived from previous investigations and literature references. Based on this information, different numerical models are used to reconstruct the damages.

Different three-dimensional FE models, endowed with an elastic plastic (softening) damage constitutive law, are adopted to determine the seismic vulnerability of the building by means of nonlinear static analyses using the smeared fracture energy approach. With this method it is possible to establish, with a right degree of approximation, the areas where the most important cracks are expected and, in general, the location of the potential damage caused by horizontal forces.
\end{abstract}




\section{INTRODUCTION}

Italy in the last years was hit by several earthquakes, the last one was that of 2016/2017 Central Italy, characterized by four principal shooks: $24^{\text {th }}$ August $2016 \mathrm{Mw}=6.0,26^{\text {th }}$ October $2016 \mathrm{Mw}=5.9,30^{\text {th }}$ October $2016 \mathrm{Mw}=6.5$ and $18^{\text {th }}$ January $2017 \mathrm{Mw}=5.5$. This swarm interested a large area between Marche, Abruzzo, Lazio and Umbria regions. These areas are characterized by spread little villages with many religious buildings, having been territories belonging to Papal State up to 1870 . The churches showed, again, their high vulnerability to the horizontal forces [1-12], due to their complex geometry and state of conservation. Whit the aim to find an appropriate method to evaluate the actual vulnerability and to predict the possible seismic damages of these structures, three different churches were analyzed. The case studies are in Camerino, a village in Marche Region hinterland. Camerino has been often hit by strong quakes (Figure 1), noteworthy is the 1799 swarm with a maximum intensity of 6.1 that provoked 60 dead in the village and heavy damages at the structures.

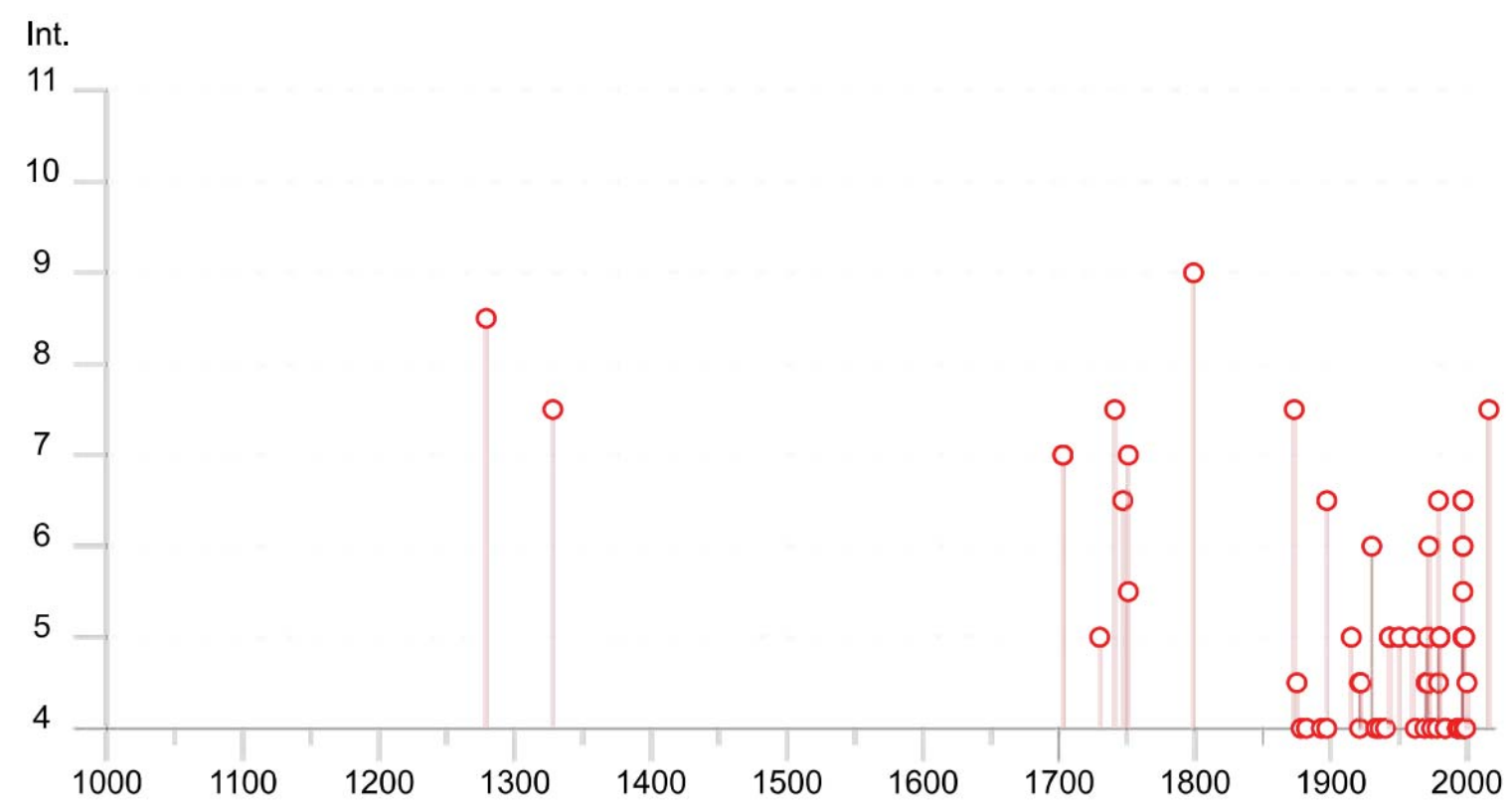

Figure 1 Earthquakes felt in Camerino during the years, from 1000 to 2017 (https://emidius.mi.ingv.it/ [13])

The analyzed churches are shown in Figure 2, they are:

- Santa Maria in Via Church

- San Venanzio Church

- Santa Maria Annunziata Church

Two of them are in the red zone, Santa Maria in Via and Santa Maria Annunziata, whereas San Venanzio is in Nord-Est neighborhood. The churches were studied using 3D Finite Element Models, on with whom linear and non-linear analyses were carried out in order to stress, once again, the capacity of this modeling type to predict the seismic vulnerability, since it would be a useful resource to design interventions to prevent cracks and failures occurrence $[14,15]$. 


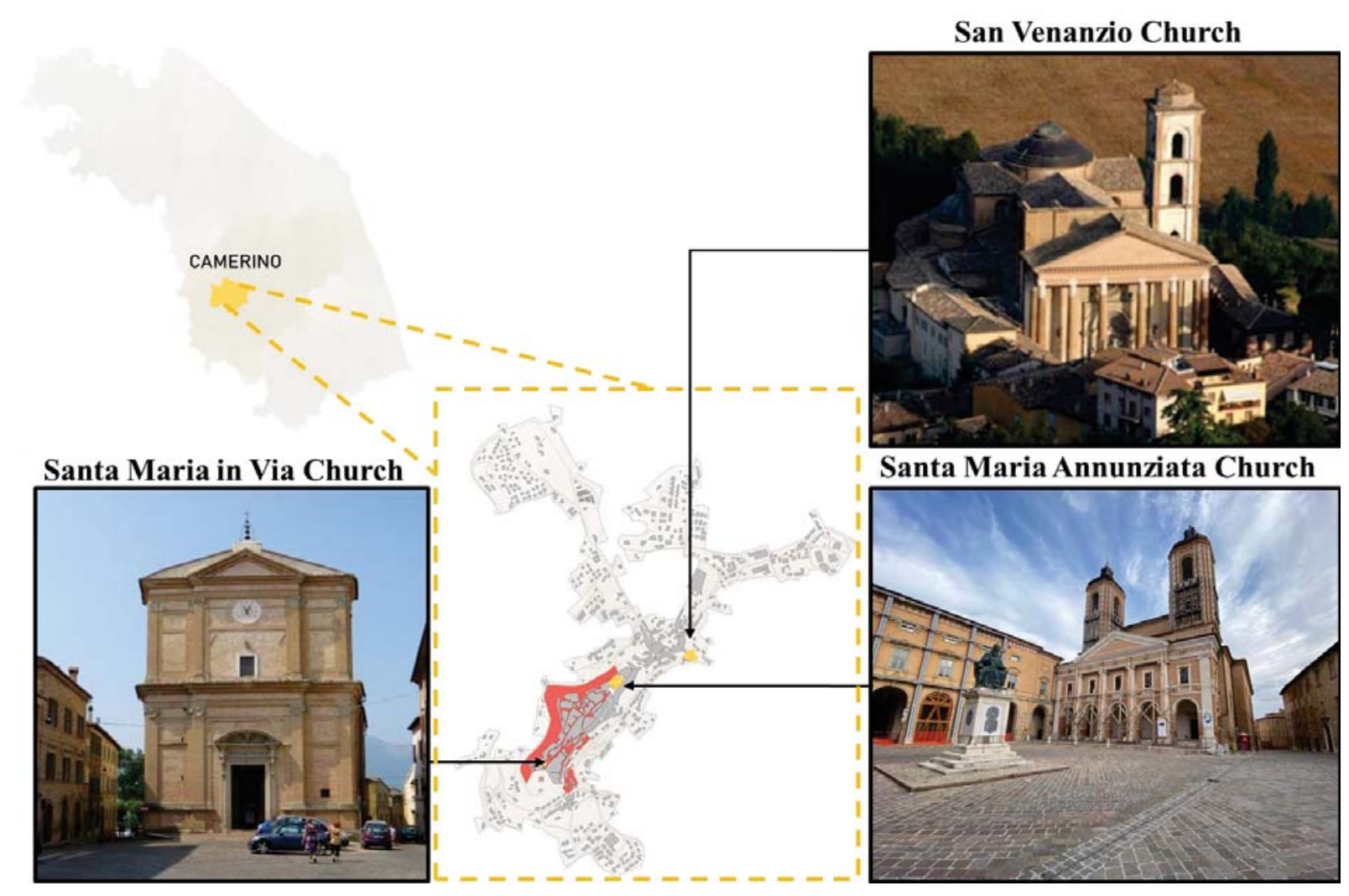

Figure 2 Geographical localization of the churches analyzed

\section{CASE STUDIES}

\subsection{Historical development}

\section{Santa Maria in Via Church (S_M_V)}

The firsts proofs of a church presence date back to 1299 , it was probably a little church that was converted later to guard the Madonna enthroned with the child, painting brought by Crusaders from Smirne. The church reformation started in 1639 by the Angelo Giori Cardinal will and ended in 1642. The church was hit by different earthquakes during the centuries, the strong 1799 quake caused the collapse of the masonry vault that covered the principal room, that was replaced by a camorcanna vault (light vault). During the 1997 Earthquake, there were static damages and in the connections of the light vault with the trusses od roof. The work of restoration was completed only in 2006.

\section{San Venanzio Church (S_V)}

San Venanzio Church dates back to the XII century, it was built on the ruins of a little church erected on the place of Saint's martyrium. In the XIII century, the church acquired importance and became Collegiata. The church was subject to different works during the years, subsequently the 1799 earthquake was necessary a radical reconstruction for the heavy damage suffered. The works were carried out by the architect Luigi Poletti, they started in 1836 and ended in 1875 on the 9 of May. In 1979 the transept foundations were consolidated with micro piles and the principal walls were reinforced by concrete injections. In the "90s also the crypt columns' foundations were consolidated. During the "97 earthquakes, the failure of sac- 
risty and apse foundations occurred. After this event also these foundations were reinforced with R.C. piles and the roofs and masonry walls were repaired.

\section{Santa Maria Annunziata Church (S_M_A)}

The first the structure edification seems to date back to the $\mathrm{V}$ century, while the first proof of a Romanesque church, consecrated to San Giuseppe, date to the XIII century. The first important interventions go back to 1259 when the Svevi's devastation and the population increment pushed on a complete renovation. In 1279 the church was hit by a strong earthquake, it provoked the bell-tower collapse, that was rebuilt subsequently. In 1748/49 the façade was transformed by a two hundred style at Barocco style. The $28^{\text {th }}$ June of 1799 a new earthquake hit the church, followed by a heavy makeover carried out by Andrea Vinci architect, a Vanitelli's student. The new church had a portico in front as an extension of the Palazzo Vescovile. The works ended the $8^{\text {th }}$ of September of 1932, when the church was devoted to Santissima Maria Annunziata. After the "97 earthquake the church was reinforced by steel connections on the roof base to provide the box-behavior.

\subsection{Geometric survey}

\section{Santa Maria in Via Church (S_M_V)}

The nave of the church has an elliptic shape with a larger diameter of about $28 \mathrm{~m}$ and smaller of $13 \mathrm{~m}$, on both sides there are four chapels (Figure 3-a). On the two sides of the entry, there are two symmetric rooms that are a baptizer and a chapel. The sacristy and the oratory are on the sides of the presbytery. On the south side, there is the bell-tower high $15 \mathrm{~m}$. The bearing structure is made of solid bricks with an inner core of poor materials. The hall is covered by a camorcanna vault and the roof is made by wood trusses

\section{San Venanzio}

The basilica has a Latin-cross (39mx68m) layout with the principal nave of double-length respect the lateral ones Figure 3-b. The principal nave is divided by the others whit fourteen Corinthian columns built with blocks stone and solid bricks. Under the presbytery, there is the crypt covered by cross vaults supported by Porfido columns. The crypt is accessed through two symmetrical stairs in the transept. The bell-tower is on the north-west side with a height of $45 \mathrm{~m}$, three different orders are visible on it. On the principle nave there is a light barrel vault covered by a wood roof. The bearing structure is made of solid bricks

\section{Santa Maria Annunziata Church (S_M_A)}

The church has a Latin-cross layout $(29 \mathrm{mx} 70 \mathrm{~m})$, the naves are divided by columns and pillars on which rest round arches Figure 3-c. Under the church, there is a large crypt cover by cross and barrel vaults. On the two sides of the facade, arrears of six meters, there are two identical bell-towers of $40 \mathrm{~m}$ high covered by domes. The naves are covered by camorcanna vaults and the roof is made of wood trusses. The bearing structure is made of solid bricks and stone blocks 

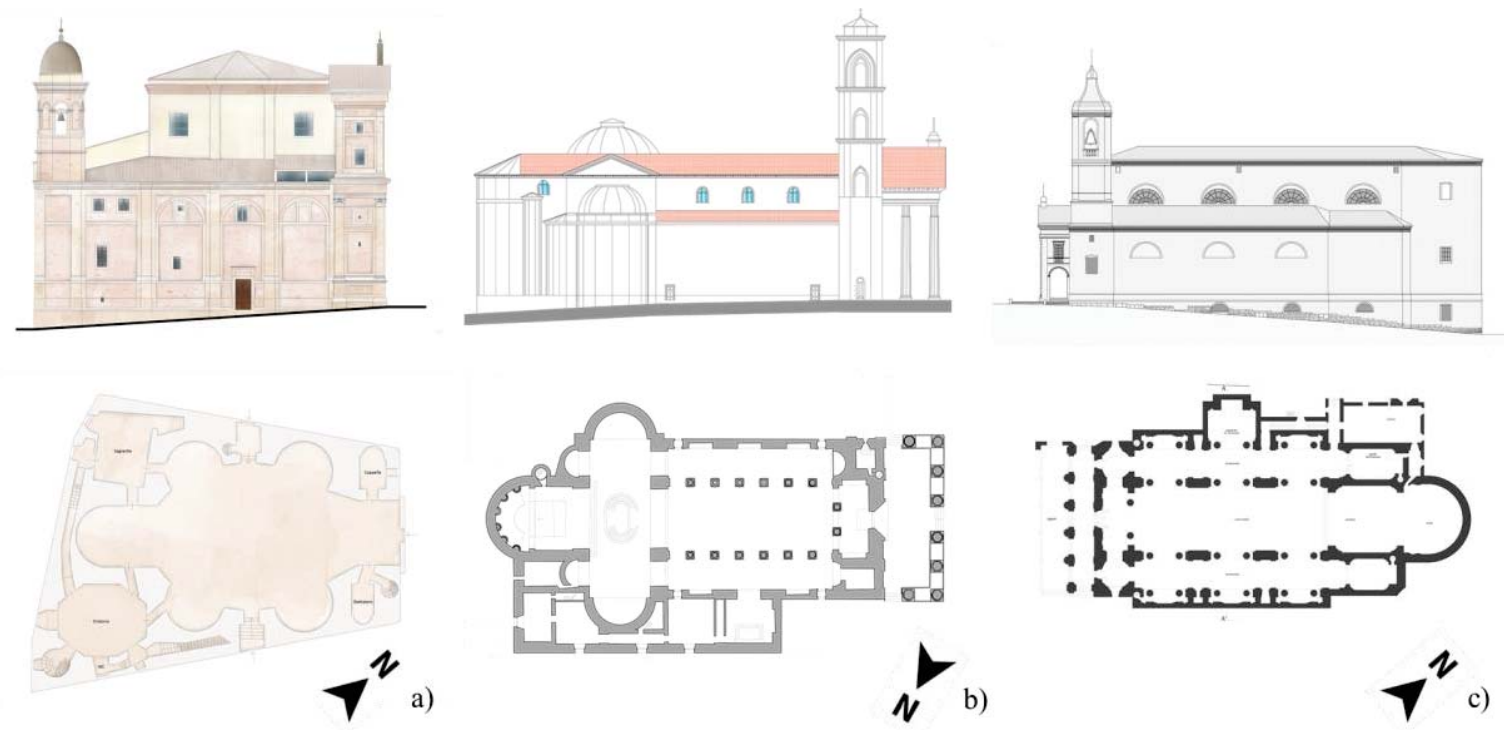

Figure 3 Geometric configuration; a) Santa Maria in Via; b) San Venanzio; c) Santa Maria Annunziata

\subsection{Damage suffered during the Central Italy Earthquake}

The 2016 earthquakes caused damages to all these churches. Indeed, comparing the accelerations recorded to Camerino during the $30^{\text {th }}$ October quake with the maximum acceleration expected to preserve the human life, according to the Italian code [16], they have been, in North direction, twice respect to expected values Figure 4.

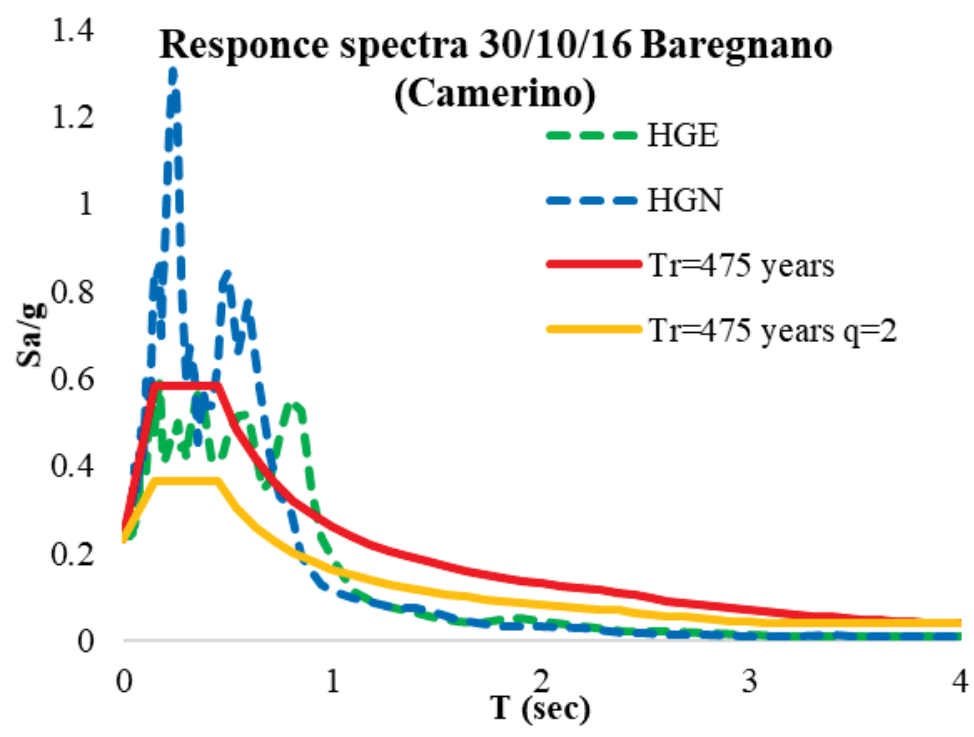

Figure 4 Comparison between the maximum acceleration expected for the SLV and accelerations recorded

The most damage church is Santa Maria in Via. After the $26^{\text {th }}$ October earthquake, the belltower collapsed and a lot of spread cracks appeared, during the $30^{\text {th }}$ October quake the cracks made worst, and partial collapses occurred on the two sides of the façade Figure 5-a. The roof collapse happened after the $18^{\text {th }}$ January 2017 earthquake, provoking the tambour and light vault failure. 
The second more damaged church is Santa Maria Annunziata Figure 5-c, it showed significative cracks in both the bell-towers in correspondence of the spiral stairs and near the façade connections. The narthex had cracks on the connection to the façade, probably provoke by a hammering mechanism. On the opposite sides of the presbytery, two symmetric cracks show the activation of its out-of-plane mechanism. The church internally had shear cracks on the pillars and between the change of materials.

San Venanzio, instead, had deep cracks on the light vaults, on the arches and walls Figure 5-b. All of them were declared unsafe after the earthquakes, today the only reopened is the less damage, or rather, San Venanzio.
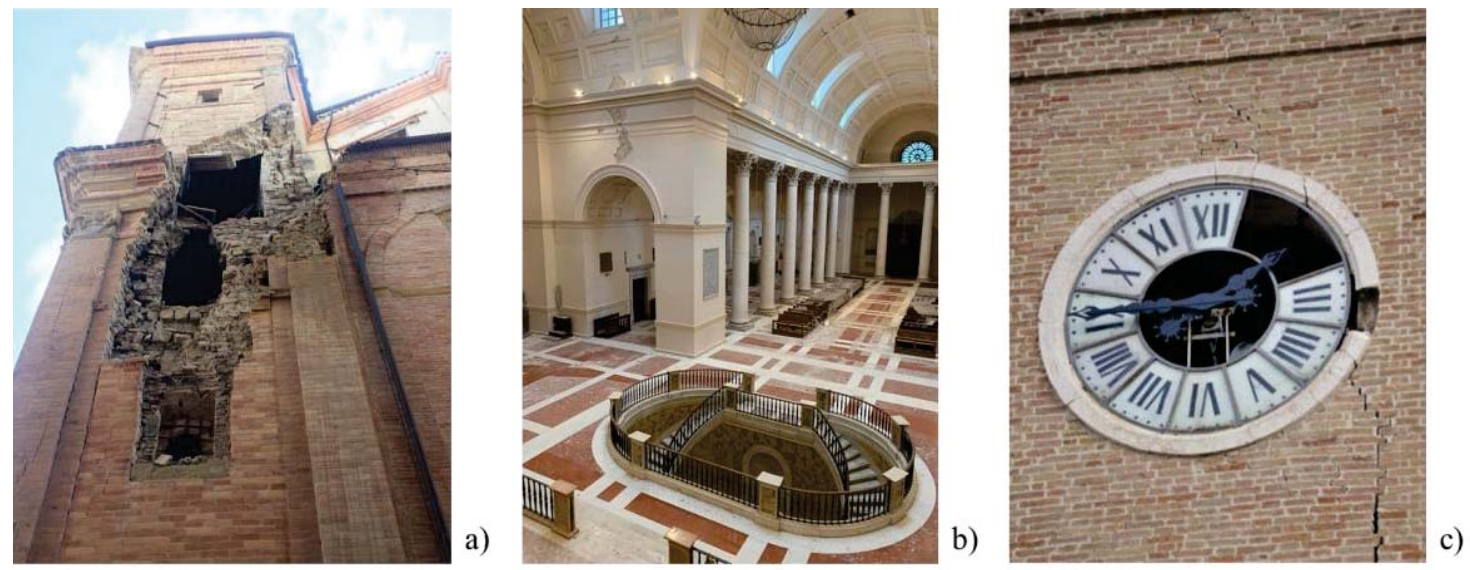

Figure 5 Some cracks after the Central Italy Earthquake, a) Partial collapse of one façade side of Santa Maria in Via; b) Cracks spread on the walls and the vault of San Venanazio; c) Crack in correspondence of the Clock of one Santissima Annunziata bell-tower

\section{NUMERICAL MODEL}

The churches were studied using Finite Element Models (FEMs), by means of MidasFEA(C) software [17], as it is impossible to simplify this type of buildings with the common softwares. The masonry was considered as homogeneous and isotropic material, whose post elastic behavior was considered using the Total Strain Crack Model, assign a parabolic law in compression, a Hordjik law in tension and a linear law for the shear [18-20].

The geometries were reproduced carefully and subsequently discretized with 4-nodes tetrahedral brick elements Figure 6. In the Table 1 are reported the number of elements, nodes and degree of freedom used for each case study.

\begin{tabular}{cccc}
\hline Church & Element & Nodes & d.o.f. \\
\hline S_M_V & 483885 & 109694 & 345414 \\
S_V & 230046 & 61422 & 175723 \\
S_M A & 601019 & 163030 & 489090 \\
\hline \multicolumn{4}{c}{ Table 1 Finite Element Models characteristics }
\end{tabular}



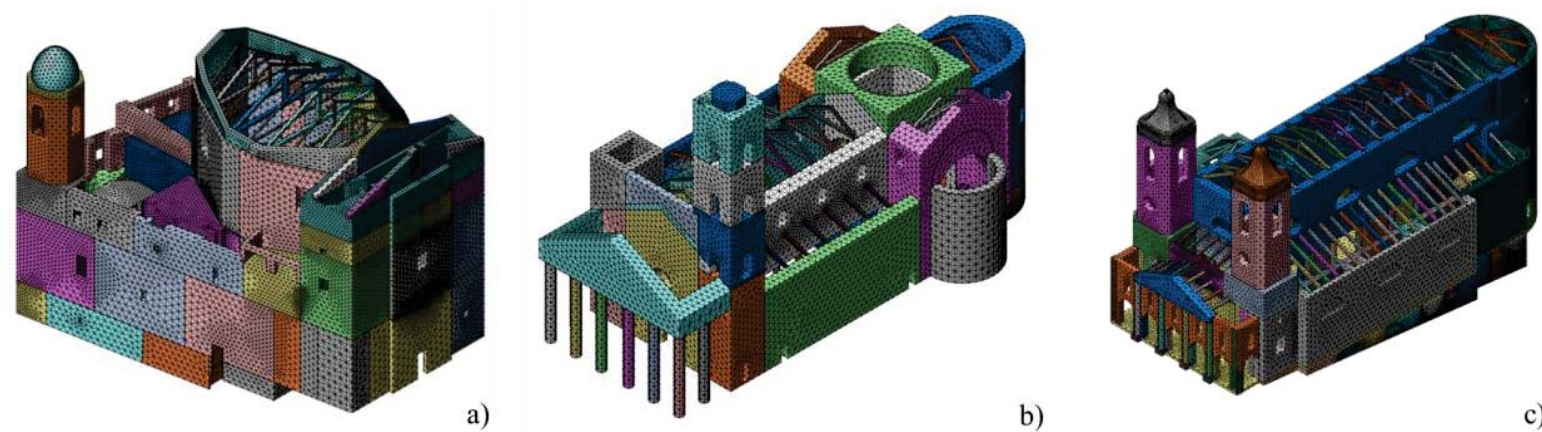

b)

c)

Figure 6 Numerical Models of a) Santa Maria in Via; b) San Venanzio; b) Santa Maria Annunziata

\subsection{Dynamic analysis}

Firstly, the numerical models were submitted to dynamic linear analyses using Lancoz method. A lot of modal shapes were necessary to move the $85 \%$ of the total mass in both the direction, the number of modes are respectively 414 for Santa Maria in via, 230 for the San Venanzio and 474 for the Santa Maria Annunziata

The principal modal shapes periods, for each church, are compared with the spectrums recorded during the strongest quake of the 2016 seismic swarm, the Figure 7 shows that their periods are near the maximum accelerations recorded periods.

In all the models the bell-towers are moved from one of the principal modes, indeed, in all the cases, they showed cracks after the earthquakes. The two long churches, San Venanzio and Santa Maria Annuziata, have as other vulnerable elements the longitudinal walls, instead, the façade is a vulnerable element for the Santa Maria in via church, in effect it has two long cracks on both sides.

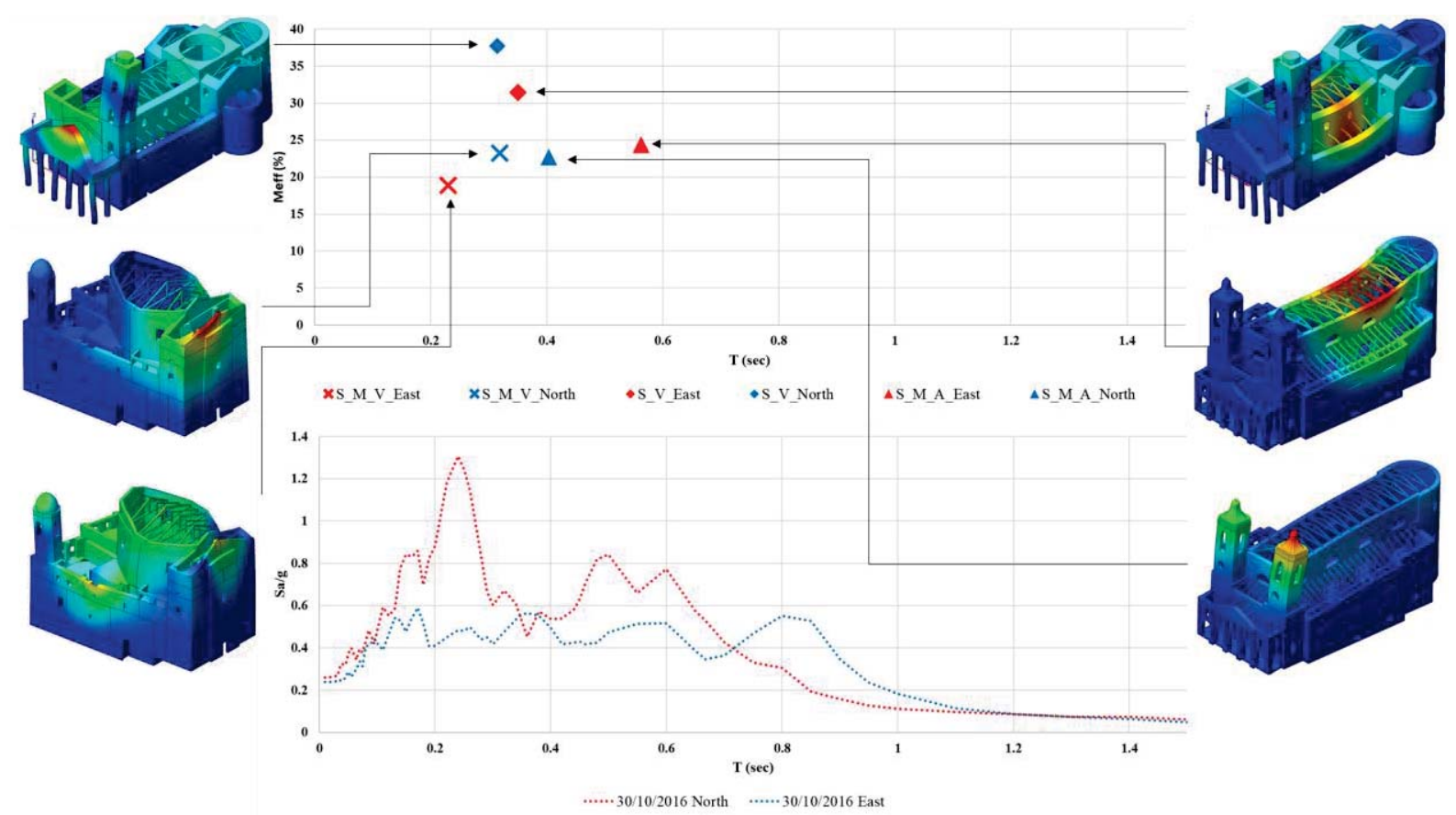

Figure 7 Distribution of principal modal shapes in the North and East directions and comparison with the pseudo-acceleration response spectra of the main shock of Central Italy 2016-2017 seismic sequence. 


\subsection{Nonlinear static analysis}

Subsequently, the models were used to carry out the non-linear static analyses, following the guidelines of the Italian Code [16,21] two different force distributions were used, one proportional to the modal shapes (PushMode) and the other masses proportional (PushMass).

To perform the PushMode the models were subjected to response spectrum analysis using as input the Limit State of Significant Damage (SLSD or SLV in Italian) spectrums considering "Class II" and ordinary structures. The nodal forces were obtained combining with the $\mathrm{CQC}$ algorithm the responses in each direction, considering the number of modes necessary to move the $85 \%$ of the total mass.

The analyses were performed using the arch-length iteration, using 0.1 as initial load, 1000 as maximum number of iteration and a $10^{-3}$ as convergence limit.

From these analyses, the capacity curves of each church were obtained for different control nodes. The curves show different behaviors and resistances for both in the directions and control nodes chosen, due to the geometry complexity. In Figure 8 are reported the capacity curves of one control node for each church obtain by PushMass analysis in $+X-D i r e c t i o n$ and + Y-Direction.
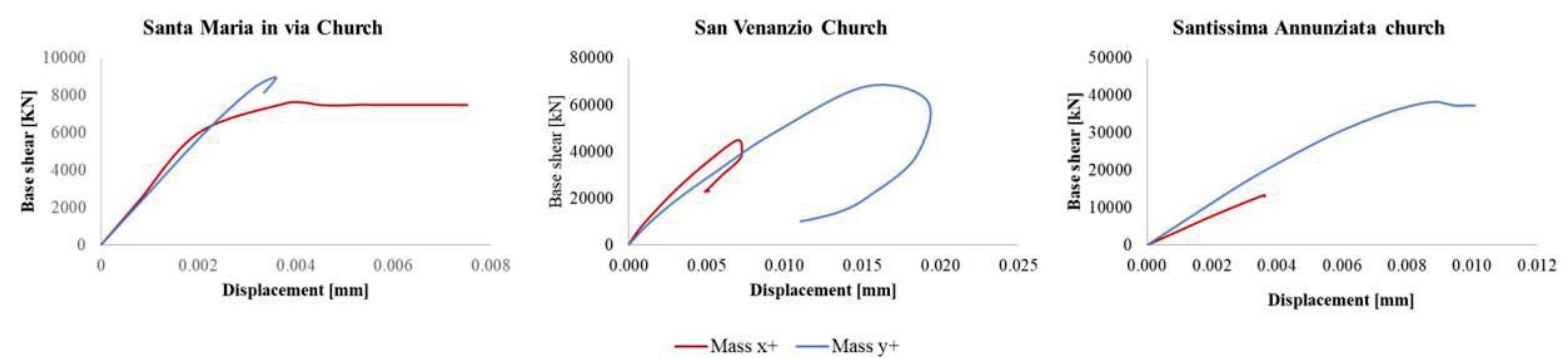

Figure 8 Examples of PushMass curves in $+\mathrm{X}$-Direction and + Y-Direction of a control node for each church

Comparing the numerical cracks with the real damages it is possible to confirm the readability of the numerical models Figure 9.
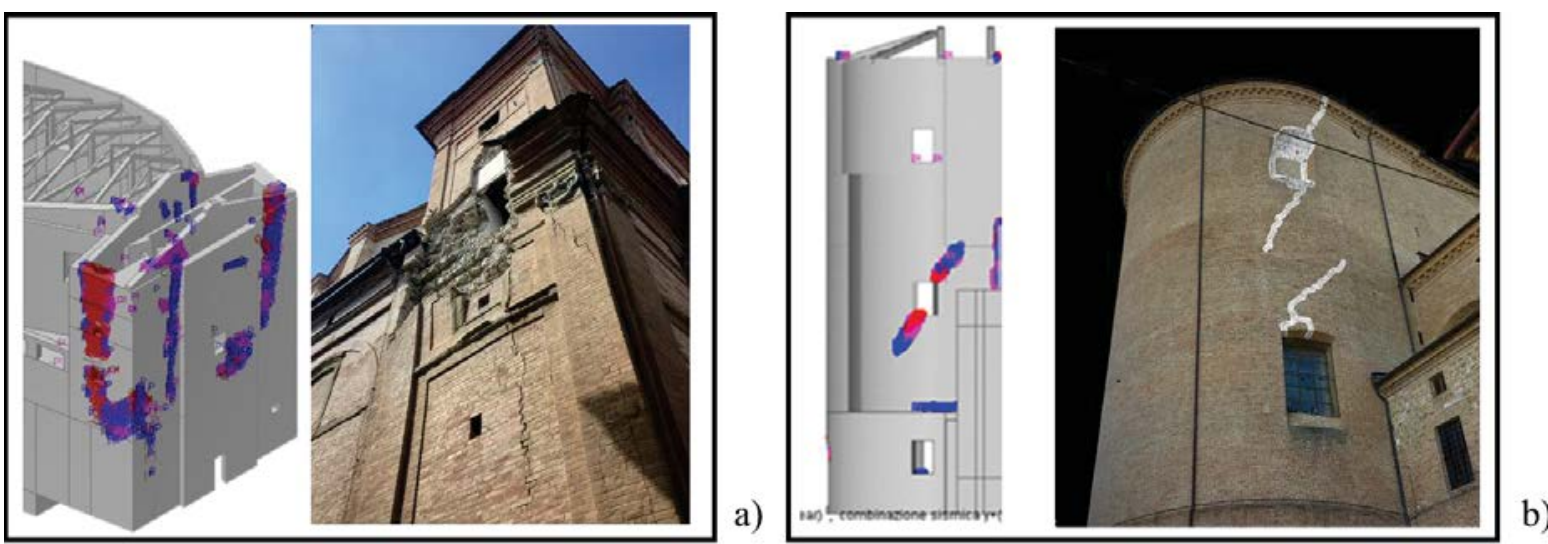

Figure 9 Correspondence between numerical and real cracks for a) Santa Maria in Via; b) Santa Maria Annunziata 


\section{CONCLUSIONS}

The paper presents an accurate study of three churches, Santa Maria in Via, San Venanzio and Santissima Annunziata, located in the crater area of 2016 Central Italy Earthquake, precisely in Camerino, a village in the hinterland of Marche Region. The churches, seriously damaged, were studied with FEM using linear and nonlinear analysis. The nonlinear static analyses show as this type of analysis is able, with a good approximation, to reproduce the real cracks occurred, even if it overestimates the seismic capacity, since it doesn't include the change of frequencies produced by the damage evolution.

\section{REFERENCES}

[1] F. Clementi, A. Ferrante, E. Giordano, F. Dubois, S. Lenci, Damage assessment of ancient masonry churches stroked by the Central Italy earthquakes of 2016 by the nonsmooth contact dynamics method, Bull. Earthq. Eng. (2019). doi:10.1007/s10518-01900613-4.

[2] E. Giordano, F. Clementi, A. Nespeca, S. Lenci, Damage Assessment by Numerical Modeling of Sant'Agostino's Sanctuary in Offida During the Central Italy 2016-2017 Seismic Sequence, Front. Built Environ. 4 (2019). doi:10.3389/fbuil.2018.00087.

[3] A. Ferrante, F. Clementi, G. Milani, Advanced numerical analyses by the Non-Smooth Contact Dynamics method of an ancient masonry bell tower, Math. Methods Appl. Sci. (2020) mma.6113. doi:10.1002/mma.6113.

[4] F. Clementi, G. Milani, A. Ferrante, M. Valente, S. Lenci, Crumbling of Amatrice clock tower during 2016 Central Italy seismic sequence: Advanced numerical insights, Frat. Ed Integrità Strutt. 14 (2019) 313-335. doi:10.3221/IGF-ESIS.51.24.

[5] G. De Matteis, M. Zizi, Preliminary Analysis on the Effects of 2016 Central Italy Earthquake on One-Nave Churches, in: 2019: pp. 1268-1279. doi:10.1007/978-3-31999441-3_136.

[6] G. Milani, M. Valente, Failure analysis of seven masonry churches severely damaged during the 2012 Emilia-Romagna (Italy) earthquake: Non-linear dynamic analyses vs conventional static approaches, Eng. Fail. Anal. 54 (2015) 13-56. doi:10.1016/j.engfailanal.2015.03.016.

[7] A. Ferrante, F. Clementi, G. Milani, Dynamic Behavior of an Inclined Existing Masonry Tower in Italy, Front. Built Environ. 5 (2019). doi:10.3389/fbuil.2019.00033.

[8] A. Formisano, G. Vaiano, F. Fabbrocino, G. Milani, Seismic vulnerability of Italian masonry churches: The case of the Nativity of Blessed Virgin Mary in Stellata of Bondeno, J. Build. Eng. 20 (2018) 179-200. doi:10.1016/j.jobe.2018.07.017.

[9] E. Giordano, F. Clementi, A. Barontini, M. Giovanna, E. Chatzi, F. Luís, Damage detection and optimal sensor placement in health monitoring of "Collegiata di Santa Maria " in Visso ( Central Italy ) Damage detection and optimal sensor placement in health monitoring of "Collegiata di Santa Maria " in Visso ( Central Italy ), (2019) 4453.

[10] E. Giordano, A. Ferrante, E. Ribilotta, F. Clementi, S. Lenci, Damage Assessment of San Francesco Church in Amandola Hit by Central Italy 2016-2017 Seismic Event, 
Key Eng. Mater. 817 (2019) 627-633. doi:10.4028/www.scientific.net/KEM.817.627.

[11] A. Ferrante, E. Ribilotta, E. Giordano, F. Clementi, S. Lenci, Advanced Seismic Analyses of "Apennine Churches" Stroked by the Central Italy Earthquakes of 2016 by the Non-Smooth Contact Dynamics Method, Key Eng. Mater. 817 (2019) 309-316. doi:10.4028/www.scientific.net/KEM.817.309.

[12] E. Ribilotta, E. Giordano, A. Ferrante, F. Clementi, S. Lenci, Tracking Modal Parameter Evolution of Different Cultural Heritage Structure Damaged by Central Italy Earthquake of 2016, Key Eng. Mater. 817 (2019) 334-341. doi:10.4028/www.scientific.net/KEM.817.334.

[13] INGV, Istituto Nazionale di Geofisica e Vulcanologia, (2020). https://emidius.mi.ingv.it/.

[14] B. Faggiano, A. Marzo, A. Formisano, F.M. Mazzolani, Innovative steel connections for the retrofit of timber floors in ancient buildings: A numerical investigation, Comput. Struct. 87 (2009) 1-13. doi:10.1016/j.compstruc.2008.07.005.

[15] A. Formisano, C. Castaldo, G. Chiumiento, Optimal seismic upgrading of a reinforced concrete school building with metal-based devices using an efficient multi-criteria decision-making method, Struct. Infrastruct. Eng. 13 (2017) 1373-1389. doi:10.1080/15732479.2016.1268174.

[16] Ministero delle Infrastrutture e dei Trasporti, DM 17/01/2018 - Aggiornamento delle "Norme Tecniche per le Costruzioni" (in italian), (2018) 1-198.

[17] Midas FEA, Analysis and Algorithm Manual, (2016).

[18] J.G. Rots, Smeared and discrete representations of localized fracture, Int. J. Fract. 51 (1991) 45-59. doi:10.1007/BF00020852.

[19] P.B. Lourenço, Recent advances in masonry modelling: micromodelling and homogenisation, in: Multiscale Model. Solid Mech. Comput. Approaches, 2009: pp. 251-294. doi:10.1142/9781848163089_0006.

[20] J.G. Rots, R. de Borst, Analysis of Mixed-Mode Fracture in Concrete, J. Eng. Mech. 113 (1987) 1739-1758. doi:10.1061/(ASCE)0733-9399(1987)113:11(1739).

[21] Ministero delle infrastrutture e dei trasporti, Circolare 21 gennaio 2019 n. 7 C.S.LL.PP. Istruzioni per l'applicazione dell'aggiornamento delle "Norme Tecniche per le Costruzioni” di cui al D.M. 17/01/2018 (in Italian), Suppl. Ord. Alla G.U. n. 35 Del 11/2/19. (2019). 